\title{
Effect of Cognitive Reserve on the Association of Vascular Brain Injury With Cognition
}

\author{
Analysis of the PURE and CAHHM Studies
}

\begin{abstract}
Romella Durrani, PhD, Matthias G. Friedrich, MD, Karleen M. Schulze, MMath, Philip Awadalla, PhD, Kumar Balasubramanian, MSc, Sandra E. Black, MD, Philippe Broet, MD, PhD, David Busseuil, PhD, Dipika Desai, MSc, Trevor Dummer, PhD, Alexander Dick, MD, Jason Hicks, MSc, Thomas lype, MD, David Kelton, MD, Anish Kirpalani, MD, Scott A. Lear, PhD, Jonathon Leipsic, MD, Wei Li, PhD, Cheryl R. McCreary, PhD, Alan R. Moody, MD, Michael D. Noseworthy, PhD, Grace Parraga, PhD, Paul Poirier, MD, PhD, Sumathy Rangarajan, MSc, Dorota Szczesniak, PhD, Andrzej Szuba, MD, Jean-Claude Tardif, MD, Koon Teo, MBBCH, PhD, Jennifer E. Vena, PhD, Katarzyna Zatonska, MD, Anna Zimny, MD, Douglas S. Lee, MD, PhD, Salim Yusuf, MBBS, DPhil, Sonia S. Anand, MD, PhD, and Eric E. Smith, MD, MPH
\end{abstract}

Neurology ${ }^{\circledR}$ 2021;97:e1707-e1716. doi:10.1212/WNL.0000000000012765

\author{
Correspondence \\ Dr. Smith \\ eesmith@ucalgary.ca
}

\begin{abstract}
\section{Background and Objectives}

To determine whether cognitive reserve attenuates the association of vascular brain injury with cognition.
\end{abstract}

\section{Methods}

Cross-sectional data were analyzed from 2 harmonized studies: the Canadian Alliance for Healthy Hearts and Healthy Minds (CAHHM) and the Prospective Urban and Rural Epidemiology (PURE) study. Markers of cognitive reserve were education, involvement in social activities, marital status, height, and leisure physical activity, which were combined into a composite score. Vascular brain injury was defined as nonlacunar brain infarcts or high white matter hyperintensity (WMH) burden on MRI. Cognition was assessed using the Montreal Cognitive Assessment Tool (MoCA) and the Digit Symbol Substitution Test (DSST).

\section{Results}

There were 10,916 participants age 35-81. Mean age was 58.8 years (range 35-81) and 55.8\% were female. Education, moderate leisure physical activity, being in a marital partnership, being taller, and participating in social groups were each independently associated with higher cognition, as was the composite cognitive reserve score. Vascular brain injury was associated with lower cognition ( $\beta-0.35$ [95\% confidence interval [CI] -0.53 to -0.17 ] for MoCA and $\beta-2.19$ [95\% CI -3.22 to -1.15$]$ for DSST) but the association was not modified by the composite cognitive reserve variable (interaction $p=0.59$ for MoCA and $p=0.72$ for DSST).

\begin{abstract}
From the Department of Clinical Neurosciences and Hotchkiss Brain Institute (R.D., E.E.S.) and Departments of Radiology and Clinical Neurosciences (C.R.M.), University of Calgary; Department of Medicine and Diagnostic Radiology (M.G.F.), McGill University, Montreal; Population Health Research Institute, Hamilton Health Sciences (K.M.S., K.B., D.D., S.R., K.T., S.Y., S.S.A.), Department of Medicine (K.M.S., K.B., S.R., K.T., S.Y., S.S.A.), Department of Electrical and Computer Engineering, School of Biomedical Engineering (M.D.N.), and Department of Health Evidence and Impact (K.T., S.Y., S.S.A.), McMaster University, Hamilton; Department of Molecular Genetics, Ontario Institute for Cancer Research (P.A.), Department of Medicine (Neurology) (S.B.), Sunnybrook Research Institute (S.B.), and Department of Medical Imaging (A.R.M.), Sunnybrook Health Sciences Centre, University of Toronto; Department of Medical Imaging, St. Michael's Hospital (A.K.), and Department of Medicine, ICES (D.S.L.), University of Toronto; Department of Preventive and Social Medicine, École de Santé Publique (P.B.), and Research Centre, Montreal Heart Institute (D.B., J.-C.T.), Université de Montréal; Research Centre (P.B.), CHU Sainte-Justine, Montreal; School of Population and Public Health (T.D.) and Department of Radiology, St. Paul's Hospital (J.L.), University of British Columbia, Vancouver; Division of Cardiology (A.D.), University of Ottawa Heart Institute, University of Ottawa; Atlantic PATH (.H.), Dalhousie University, Halifax, Canada; Department of Neurology (T.I.), Government Medical College Thiruvananthapuram, India; Diagnostic Imaging (D.K.), Brampton Civic Hospital, William Osler Health System, Etobicoke; Faculty of Health Sciences (S.A.L.), Simon Fraser University, Burnaby, Canada; National Center for Cardiovascular Diseases (W.L.), Chinese Academy of Medical Sciences, Fu Wai Hospital, Beijing, China; Diagnostic Imaging (M.D.N.), St. Joseph's Health Care, Hamilton; Department of Medical Biophysics and Robarts Research Institute (G.P.), Western University, London; Institut de Cardiologie et de Pneumologie de Quebec (P.P.), Université Laval, Canada; Departments of Psychiatry (D.S.), Angiology (A.S.), Social Medicine (K.Z.), and General and Interventional Radiology and Neuroradiology (A.Z.), Wroclaw Medical University, Poland; and Cancer Research and Analytics (J.E.V.), Cancer Care Control Alberta, Alberta Health Services, Calgary, Canada.
\end{abstract}

Go to Neurology.org/N for full disclosures. Funding information and disclosures deemed relevant by the authors, if any, are provided at the end of the article.

The Article Processing Charge was funded by the authors.

This is an open access article distributed under the terms of the Creative Commons Attribution-NonCommercial-NoDerivatives License 4.0 (CC BY-NC-ND), which permits downloading and sharing the work provided it is properly cited. The work cannot be changed in any way or used commercially without permission from the journal. 


\section{Glossary}

CAHHM = Canadian Alliance for Healthy Hearts and Healthy Minds; CBI = covert brain infarct; $\mathbf{C I}=$ confidence interval; DSST = Digit Symbol Substitution; FLAIR = fluid-attenuated inversion recovery; LADIS = Leukoaraiosis and Disability; MET = metabolic equivalent; MoCA = Montreal Cognitive Assessment; PURE-Mind = Prospective Urban and Rural Epidemiology Mind substudy; WMH = white matter hyperintensities.

\section{Conclusions}

Both vascular brain injury and markers of cognitive reserve are associated with cognition. However, the effects were independent such that the adverse effects of covert vascular brain injury were not attenuated by higher cognitive reserve. To improve cognitive brain health, interventions to both prevent cerebrovascular disease and promote positive lifestyles are needed.

Clinical and postmortem studies report variations in risk for dementia despite the same type and degree of brain pathology. ${ }^{1}$ The factors that lead to this variation in cognition have been termed cognitive reserve. ${ }^{1}$ Individuals with greater cognitive reserve are hypothesized to have better functioning brains that can tolerate brain pathologic changes without exhibiting impairment.

Most of the research on cognitive reserve has focused on markers that influence the expression of Alzheimer disease pathology in older individuals, with comparatively few studies of cognitive reserve in midlife or of cognitive dysfunction from cerebrovascular pathology. ${ }^{2}$ A few studies suggest that the association of white matter hyperintensities (WMH) with lower cognition is attenuated in persons with higher education. ${ }^{3}$ However, whether other potential factors modify the degree of cognitive dysfunction in persons with WMH is not known. Such potential modifiers include social and behavioral function such as level of social engagement, marital status, height, and physical activity.

We analyzed data from 2 large population-based studies: the Canadian Alliance for Healthy Hearts and Healthy Minds (CAHHM) cohort study ${ }^{4}$ and the Prospective Urban and Rural Epidemiology Mind substudy (PURE-Mind). ${ }^{5}$ First, we tested the association between MRI vascular brain injury and cognition. Next, we tested the association between cognition and cognitive reserve markers. Finally, we created a cognitive reserve composite score and tested whether the association between vascular brain injury and cognition was modified by high compared to low levels of cognitive reserve, as assessed by the composite score.

\section{Methods}

\section{Study Population}

This was a cross-sectional analysis of participants enrolled in 2 cohort studies with harmonized assessments of risk factors, MRI, and cognitive outcomes (Figure 1). Our analysis is crosssectional. Due to the similarities and ability to harmonize data between the 2 cohort studies, we pooled data between the studies. Participants provided written informed consent. The study was approved by local institutional review boards.

CAHHM is a collaboration of several prospective longitudinal cohort studies that examine socioenvironmental and contextual factors of cardiovascular, cerebrovascular, and subclinical disease and cognition. ${ }^{4}$ CAHHM includes participants recruited from 2013 to 2019 from 14 sites from 8 previously established study cohorts: the CanPath-Canadian Partnership for Tomorrow's Health (formerly CPTP) Cohorts (BC Generations Project, Alberta's Tomorrow Project, Ontario Health Study, CARTaGENE, and Atlantic $\mathrm{PATH}^{6}$ ), the Chinese Canadian Alliance cohort, and the Montreal Heart Institute Biobank. Participants were 35-69 years of age.

PURE is a prospective study of the determinants of health in 26 countries. ${ }^{7}$ For this analysis, additional data were used from Canadian, Chinese, Indian, and Polish participants in the Mind substudy of PURE, who agreed to have a brain MRI and cognitive testing. ${ }^{5}$ These participants were recruited between 2010 and 2016 from 55 urban and rural Canadian communities from 4 Canadian cities (Vancouver, British Columbia; Hamilton and Ottawa, Ontario; and Quebec City, Quebec); 1 site in Poland (recruiting inhabitants of Lower Silesia); 3 sites in India (in Bangalore, Jaipur, and Thiruvananthapuram); and 1 site in Beijing, China. Participants were age 35-81 and had no prior history of stroke, dementia, or other CNS diseases.

\section{Assessments}

Medical history, demographics, lifestyle (individual and household level and neighborhood walkability), anthropometric measures, cognition, and MRI were recorded at enrollment. The CAHHM study was designed to use the same data elements harmonized with PURE to enable combined analyses of the 2 studies.

Markers of cognitive reserve were chosen based on literature reviews and availability of the variables in the database. We specified 6 markers of cognitive reserve: education, involvement in social groups, marital status, level of stress, height, and level of leisure physical activity. ${ }^{1,8-11} \mathrm{We}$ dichotomized all variables. Education was classified as college 
Figure 1 Association of Markers of Cognitive Reserve With Montreal Cognitive Assessment (MoCA) Score and Digit Symbol Substitution Test (DSST)

A. Montreal Cognitive Assessment

$\begin{array}{lr}\text { Cognitive reserve variable } & \text { Estimate }(95 \% \mathrm{CI}) \\ \text { College or university education } & 1.10(0.99-1.21) \\ \text { Participates in social groups } & 0.26(0.15-0.36) \\ \text { Married/common law } & 0.12(0.01-0.22) \\ \text { Moderate/high daily stress levels } & 0.00(-0.10-0.10) \\ \text { Physical height } \geq \text { sex-specific median } & 0.16(0.06-0.25) \\ \text { Moderate/high leisure physical activity } & 0.09(-0.00-0.18)\end{array}$

B. Digit Symbol Substitution Test

$\begin{array}{lr}\text { Cognitive reserve variable } & \text { Estimate }(95 \% \mathrm{CI}) \\ \text { College or university education } & 5.02(4.41-5.63) \\ \text { Participates in social groups } & 1.05(0.47-1.63) \\ \text { Married/common law } & 1.29(0.69-1.90) \\ \text { Moderate/high daily stress levels } & -0.35(-0.91-0.21) \\ \text { Physical height } \geq \text { sex-specific median } & 1.17(0.64-1.71) \\ \text { Moderate/high leisure physical activity } & 1.45(0.91-1.99)\end{array}$

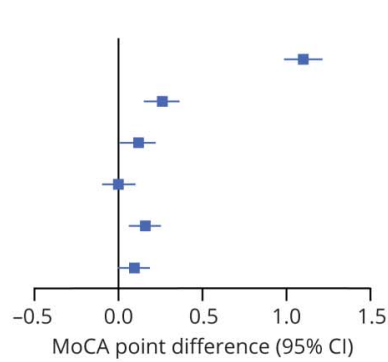

$p$ value

$<0.0001$

$<0.0001$

0.03

0.97

0.001

0.06

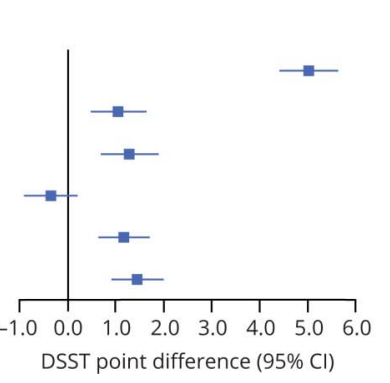

$p$ value

$<0.0001$

$<0.001$

$<0.0001$

0.22

$<0.0001$

$<0.0001$

(A) MoCA. (B) DSST. Mixed models include random (center) intercepts and fixed effects for age, sex, ethnicity, education, and all variables shown in the figure. $\mathrm{Cl}=$ confidence interval.

or university, high school or trade school, or less education; social activities were assessed by asking if participants are members of an organized social group; marital status was defined as currently being in a married or common law partnership; stress was dichotomized as moderate or severe stress vs low stress and was captured through a self-reported questionnaire previously used in the INTERHEART study, $^{12}$ where moderate or severe stress consisted of several periods of work or home stress, or permanent work or home stress; height was stratified by sex and dichotomized at sexspecific medians of above or below $163 \mathrm{~cm}$ for females and above or below $176 \mathrm{~cm}$ for males (we included height since prior literature suggests that it may have protective effects against dementia ${ }^{13}$; we hypothesize it may be a proxy for early-life development); leisure physical activity was captured based on self-report of number of hours per week or the equivalent number of metabolic equivalent (MET) minutes ( $\geq 960$ METs) on the International Physical Activity Questionnaire $^{14}$ and dichotomized as moderate to high (more than 4 hours per week or the equivalent number of MET minutes $[\geq 960$ METs]) vs low. The social activities question was not assessed in the Chinese cohort; therefore, the 466 participants from China (4.2\%) were omitted from the analysis of cognitive reserve and the interaction of cognitive reserve with vascular brain injury. While brain imaging and cognition were measured at the same visit in all cohorts, some risk factors related to cognitive reserve were measured at a prior visit. In the PURE study $(n=3,880)$, assessments were done a median of 6.7 years prior to the MRI and cognitive assessment (interquartile range 3.8-8.6 years), while in the CAHHM cohorts the cognitive reserve variables were captured at the time of the MRI and cognitive assessment, except for education and marital status, which were assessed a median of 5.0 years prior (interquartile range 4.0-6.0 years).

Cognition was assessed using the Montreal Cognitive Assessment (MoCA) and the Wechsler Adult Intelligence Scale, 4th Edition, Digit Symbol Substitution Test (DSST) ${ }^{15,16}$ in both studies. Participants were provided 120 seconds to complete the DSST. DSST was not administered in the Chinese cohort. MoCA and DSST were treated as continuous variables for this analysis. To explore potential associations with cognitive subdomains, MoCA questions were grouped into 6 domains (memory, executive function, visuospatial function, language, attention, and orientation) based on a prior publication. ${ }^{17}$

The MRI acquisition measures were harmonized between the 2 studies. In the CAHHM study, only high-resolution T1weighted and T2-weighted fluid-attenuated inversion recovery (FLAIR) sequences were acquired. In the PURE-Mind study, the following sequences were acquired: high-resolution T1-weighted, dual echo proton density/T2-weighted, T2*weighted gradient recalled echo, and FLAIR. The MRI sequences in these studies have been validated as part of the Canadian Dementia Imaging Protocol. ${ }^{18}$ There were 5,075 participants scanned at $1.5 \mathrm{~T}$ and 5,841 scanned at 3.0T.

MRI data were analyzed by a combined central core laboratory at the University of Calgary and Sunnybrook Hospital, Toronto, Canada. Each scan was visually reviewed for 
Table 1 Characteristics of the Study Population

\begin{tabular}{|c|c|c|}
\hline Characteristics & $\begin{array}{l}\text { \% or mean } \\
\text { (SD) }\end{array}$ & $n / N$ \\
\hline Female & 55.8 & $\begin{array}{l}6,094 / \\
10,916\end{array}$ \\
\hline \multicolumn{3}{|l|}{ Age, y } \\
\hline $35-49$ & 18.2 & $\begin{array}{l}1987 / \\
10,916\end{array}$ \\
\hline $50-59$ & 36.1 & $\begin{array}{l}3,941 / \\
10,916\end{array}$ \\
\hline $60-69$ & 35.7 & $\begin{array}{l}3,898 / \\
10,916\end{array}$ \\
\hline $70-79$ & 9.9 & $\begin{array}{l}1,085 / \\
10,916\end{array}$ \\
\hline Age, y & $58.1(8.8)$ & 10,916 \\
\hline \multicolumn{3}{|l|}{ Ethnic background } \\
\hline East/Southeast Asian & 14.1 & $\begin{array}{l}1,539 / \\
10,916\end{array}$ \\
\hline White & 80.2 & $\begin{array}{l}8,752 / \\
10,916\end{array}$ \\
\hline South Asian & 3.7 & $\begin{array}{l}409 / \\
10,916\end{array}$ \\
\hline Black and others & 2.0 & $\begin{array}{l}216 / \\
10,916\end{array}$ \\
\hline \multicolumn{3}{|l|}{ Highest education completed } \\
\hline None & 2.1 & $\begin{array}{l}231 / \\
10,745\end{array}$ \\
\hline High school or less & 19.8 & $\begin{array}{l}2,124 / \\
10,745\end{array}$ \\
\hline Trade/vocational & 9.6 & $\begin{array}{l}1,034 / \\
10,745\end{array}$ \\
\hline College/university & 68.5 & $\begin{array}{l}7,356 / \\
10,745\end{array}$ \\
\hline Married/common law & 77.1 & $\begin{array}{l}8,285 / \\
10,741\end{array}$ \\
\hline Participates in social groups & 63.9 & $\begin{array}{l}6,643 / \\
10,402\end{array}$ \\
\hline $\begin{array}{l}\text { Leisure time physically active (moderate or } \\
\text { greater) }\end{array}$ & 54.2 & $\begin{array}{l}5,804 / \\
10,717\end{array}$ \\
\hline $\begin{array}{l}\text { Reported moderate or higher stress in past } \\
\text { year }\end{array}$ & 32.1 & $\begin{array}{l}3,475 / \\
10,815\end{array}$ \\
\hline Height, cm, women & $162.0(6.8)$ & 6,090 \\
\hline Height, cm, men & $175.2(7.2)$ & 4,813 \\
\hline \multicolumn{3}{|l|}{ MRI brain measures } \\
\hline CBI & 5.6 & $\begin{array}{l}612 / \\
10,916\end{array}$ \\
\hline Lacunar & 4.0 & $\begin{array}{l}442 / \\
10,916\end{array}$ \\
\hline Nonlacunar & 1.6 & $\begin{array}{l}172 / \\
10,916\end{array}$ \\
\hline$\geq 3 \mathrm{CBI}$ & 0.8 & $84 / 10,916$ \\
\hline
\end{tabular}

Table 1 Characteristics of the Study Population (continued)

\begin{tabular}{|c|c|c|}
\hline Characteristics & $\begin{array}{l}\% \text { or mean } \\
\text { (SD) }\end{array}$ & $n / N$ \\
\hline High WMH & 6.3 & $\begin{array}{l}691 / \\
10,916\end{array}$ \\
\hline \multicolumn{3}{|c|}{ Cognitive score measures } \\
\hline MoCA & $26.7(2.6)$ & 10,916 \\
\hline MoCA $\geq 26$ & 72.8 & $\begin{array}{l}7,948 / \\
10,916\end{array}$ \\
\hline DSST Score & 71.5 (16.8) & 10,450 \\
\hline \multicolumn{3}{|c|}{$\begin{array}{l}\text { Abbreviations: } \mathrm{CBI}=\text { covert brain infarct; DSST = Digit Symbol Substitution } \\
\text { Test; MoCA = Montreal Cognitive Assessment; WMH = white matte } \\
\text { hyperintensities. } \\
\text { Continuous values are mean (SD). }\end{array}$} \\
\hline
\end{tabular}

adequate quality. Covert brain infarcts (CBIs) and WMH were defined according to consensus criteria. $\mathrm{CBI}$ was defined as brain infarcts that were not associated with overt clinical symptoms of stroke ${ }^{19}$ and classified as lacunar and nonlacunar. WMH was rated according to the Fazekas scale, in which a score of $0-3$ is assigned separately to periventricular and subcortical WMH (sum 0-6), which has been validated against quantitative measurements. High $\mathrm{WMH}$ was defined as Fazekas sum score of 4-6. Vascular brain injury was defined as the presence of nonlacunar infarcts or high WMH.

\section{Statistical Analysis}

Linear mixed models with random intercepts were used to determine the relationship between brain abnormalities (nonlacunar brain infarcts, WMH, and nonlacunar infarcts) and cognition (MoCA and DSST scores). Site was included as a random intercept variable to account for site-related variations in cognition and differences in the MRI scanner. MoCA and DSST were treated as a continuous variable for analysis. Presence or absence of covert brain infarcts were recorded and WMH was categorized as high (Fazekas total score of 4-6) vs low burden. We evaluated the association of nonlacunar CBI, high WMH, and the composite (vascular brain injury) with cognition, both unadjusted and adjusted for age, sex, and ethnicity as fixed effects. Next, we considered the association of the cognitive reserve variables on the cognitive scores, each separately and all combined in 1 model. Based on the relative size of the $\beta$ coefficients from the fully adjusted model controlling for all cognitive reserve variables, a cognitive reserve composite score was created where the relative contribution of each marker was based on its effect on cognition as follows: 1 point each for participating in social groups, being in a marital partnership, being taller than the sex-specific median, and having moderate or higher leisure physical activity level; and up to 4 points were assigned for education ( 2 points for completing high school or trade school and 4 points for a university degree). Education was accorded more points than the other factors because it had a stronger estimated effect on cognition. To test for effect 
Table 2 Association of Brain Variables With Cognition

\begin{tabular}{|c|c|c|c|c|}
\hline \multirow[b]{2}{*}{ Variables } & \multicolumn{2}{|c|}{ Difference in MoCA $(95 \% \mathrm{Cl})$} & \multicolumn{2}{|c|}{ Difference in DSST $(95 \% \mathrm{CI})$} \\
\hline & Unadjusted & Adjusted & Unadjusted & Adjusted \\
\hline High WMH & $-0.84(-1.02,-0.65)$ & $-0.34(-0.52,-0.15)$ & $-8.32(-9.55,-7.08)$ & $-2.11(-3.20,-1.02)$ \\
\hline Nonlacunar CBI & $-1.01(-1.38,-0.64)$ & $-0.49(-0.84,-0.14)$ & $-9.45(-11.84,-7.06)$ & $-4.22(-6.28,-2.17)$ \\
\hline
\end{tabular}

Abbreviations: $\mathrm{CBI}$ = covert brain infarct; $\mathrm{Cl}$ = confidence interval; DSST = Digit Symbol Substitution Test; $\mathrm{MoCA}=$ Montreal Cognitive Assessment; $\mathbf{W M H}=$ white matter hyperintensities.

Adjusted for age, sex, ethnicity, education (fixed effects), and center (random effect). Nonlacunar CBIs were compared to the rest (with or without lacunar infarcts).

modification, we created models of cognition that included an interaction term between the composite cognitive reserve score and the presence of vascular brain injury. In these models, the cognitive reserve composite variables were centered on the median so that the $\beta$ coefficient for vascular brain injury represents a participant with the median cognitive reserve. Participants from China (where the social participation question was not asked) and those with missing data on covariates (423/ $10,450[4.0 \%])$ were excluded from the model; characteristics of participants with and without missing covariate data are shown in eTable 1 in the Supplement (available from Zenodo, doi.org/10.5281/zenodo.4919053). Several sensitivity analyses were undertaken to verify the robustness of the results: (1) including both lacunar and nonlacunar infarcts in the definition of vascular brain injury, (2) removing height from the cognitive reserve variable score, and (3) modeling education alone as the cognitive reserve proxy. To explore the effects of cognitive reserve on MoCA subdomains, logistic regression models were created to estimate the association of vascular brain injury, cognitive reserve composite score, and their interaction on the odds of impairment, defined as losing points on any MoCA questions within that subdomain, and adjusting also for age, sex, and education. A $p$ value of less than 0.05 was considered significant; no adjustment was made for multiple hypothesis testing. Statistical analyses were conducted using SAS v9.4 (SAS Institute).

\section{Data Availability}

Anonymized data will be shared by request from a qualified investigator.

\section{Standard Protocol Approvals, Registrations, and Patient Consents}

Written informed consent was obtained from the participants. The study was approved by local institutional review boards at each participating site.

\section{Results}

\section{Characteristics of the Study Population}

Of 11,013 CAHHM and PURE-Mind participants without a clinical history of stroke, we excluded $59(0.5 \%)$ with incomplete MRI sequences and $38(0.3 \%)$ with missing data on cognitive function, leaving 10,916 (99.1\%) for analysis (7,036 from CAHHM and 3,880 from PURE). Of the PURE participants, 2,499 were from Canada, 814 from Poland, 466 from China, and 101 from India. Characteristics of the study population are shown in Table 1.

Of the 10,916 total participants included in the analysis, 6,094 $(55.8 \%)$ were women, mean age was $58.1 \pm 8.8$ years, and $68.5 \%$ were college/university educated. The prevalence of CBI was $5.6 \%$ and high WMH $6.3 \%$. Most $(72.8 \%)$ of the participants had a MoCA score $\geq 26$. The mean MoCA score was 26.7 (SD 2.6) and the mean DSST score was 71.5 (SD 16.8).

\section{Association of Vascular Brain Injury With Cognition}

After adjusting for sex, age, ethnicity, education, and study center, the presence of high WMH and nonlacunar CBI were associated with both lower MoCA and DSST scores (Table 2).

\section{Association of Socio-behavioral Variables, Height, and Physical Activity With Cognition}

Of the 6 cognitive reserve variables, education had the strongest association with cognition after adjustment for the other 5 cognitive reserve variables (Figure 1). Of the other 5 variables, 3 (participating in social groups, being in a marital partnership, being taller [for both sexes]) were associated with higher MoCA, and 4 (participating in social groups, being in a marital partnership, being taller [for both sexes], more leisure physical activity) were associated with higher DSST (Figure 1).

\section{Modifying Effects of Cognitive Reserve Variables on the Association of Vascular Brain Injury With Cognition}

Table 3 and Figure 2 show the modifying effects of the cognitive reserve composite score on the relationships between vascular brain injury and cognition. Vascular brain injury (either nonlacunar CBI or high WMH) was independently associated with lower scores on the MoCA $(p<0.001)$ and DSST $(p<0.0001)$. Higher cognitive reserve composite score was associated with higher scores on both DSST $(p<0.0001)$ and MoCA $(p<0.0001)$. However, the association of vascular brain injury with MoCA was not modified by the cognitive reserve composite score ( $\beta$ coefficient 0.03 , 95\% confidence 
Table 3 Modifying Effect of Cognitive Reserve Composite Score on the Association Between Vascular Brain Injury (VBI) and Cognitive Scores

\begin{tabular}{|c|c|c|c|c|}
\hline \multirow[b]{2}{*}{ Predictors of MoCA } & \multicolumn{2}{|c|}{$\begin{array}{l}\text { Without interaction between VBI and } \\
\text { cognitive reserve score }\end{array}$} & \multicolumn{2}{|c|}{$\begin{array}{l}\text { With interaction between VBI and cognitive } \\
\text { reserve score }\end{array}$} \\
\hline & $\begin{array}{l}\text { Estimated difference in } \\
\text { MoCA }(95 \% \mathrm{Cl})\end{array}$ & $p$ Value & $\begin{array}{l}\text { Estimated difference in } \\
\text { MoCA }(95 \% \mathrm{Cl})\end{array}$ & $p$ Value \\
\hline Age (by 10 years) & $-0.53(-0.58,-0.47)$ & $<0.0001$ & $-0.53(-0.58,-0.47)$ & $<0.0001$ \\
\hline Female & $0.50(0.41,0.59)$ & $<0.0001$ & $0.50(0.41,0.59)$ & $<0.0001$ \\
\hline VBI & $-0.37(-0.54,-0.19)$ & $<0.0001$ & $-0.35(-0.53,-0.17)$ & $<0.001$ \\
\hline $\begin{array}{l}\text { Cognitive reserve composite score (per additional } \\
\text { point) }\end{array}$ & $0.34(0.31,0.37)$ & $<0.0001$ & $0.34(0.31,0.37)$ & $<0.0001$ \\
\hline \multicolumn{3}{|l|}{ Interaction: $\mathrm{VBI}$ * cognitive reserve composite } & $0.03(-0.07,0.13)$ & 0.59 \\
\hline & \multicolumn{2}{|c|}{$\begin{array}{l}\text { Without interaction between VBI and } \\
\text { cognitive reserve score }\end{array}$} & \multicolumn{2}{|c|}{$\begin{array}{l}\text { With interaction between VBI and cognitive } \\
\text { reserve score }\end{array}$} \\
\hline Predictors of DSST & $\begin{array}{l}\text { Estimated difference in } \\
\text { DSST }(95 \% \mathrm{CI})\end{array}$ & $p$ Value & $\begin{array}{l}\text { Estimated difference in } \\
\text { DSST }(95 \% \mathrm{Cl})\end{array}$ & $p$ Value \\
\hline Age (by 10 years) & $-7.53(-7.83,-7.23)$ & $<0.0001$ & $-7.53(-7.83,-7.23)$ & $<0.0001$ \\
\hline Female & $6.82(6.31,7.33)$ & $<0.0001$ & $6.82(6.31,7.33)$ & $<0.0001$ \\
\hline VBI & $-2.24(-3.24,-1.24)$ & $<0.0001$ & $-2.19(-3.22,-1.15)$ & $<0.0001$ \\
\hline $\begin{array}{l}\text { Cognitive reserve composite score (per additional } \\
\text { point) }\end{array}$ & $1.83(1.65,2.01)$ & $<0.0001$ & $1.82(1.63,2.00)$ & $<0.0001$ \\
\hline Interaction: $\mathrm{VBI}$ * cognitive reserve composite & & & $0.10(-0.46,0.67)$ & 0.72 \\
\hline
\end{tabular}

Abbreviations: $\mathrm{Cl}$ = confidence interval; DSST = Digit Symbol Substitution Test; MoCA = Montreal Cognitive Assessment.

Models also adjusted for center (random intercepts) and ethnicity as a fixed effect. VBI defined as presence of either nonlacunar infarcts or high white matter hyperintensity. The cognitive reserve score consists of 1 point each for participation in social groups, being in a marital partnership, taller than sex-specific median height, and moderate or higher physical activity; and 0, 2, 2, or 4 points for less than high school, high school, trade school, or college/university education.

interval $[\mathrm{CI}]-0.07$ to 0.13 , interaction $p=0.59)$. Similarly, the association between vascular brain injury and DSST was not modified by the cognitive reserve composite score $(\beta$ coefficient $0.10,95 \% \mathrm{CI}-0.46$ to 0.67 , interaction $p=0.72$ ).

\section{Sensitivity Analyses}

The associations between vascular brain injury, cognitive reserve proxies, and cognition were essentially unchanged in sensitivity analyses (full results available at Zenodo, doi.org/10.5281/zenodo.4919053) including lacunar infarcts (Supplemental eTable 2), excluding height (Supplemental eTable 3), or using education alone as the proxy for cognitive reserve (Supplemental eTable 4). In analyses of MoCA subdomains (Supplemental eTable 5), the cognitive reserve composite score was associated with all subdomains, while the vascular brain injury variable was associated with impairments in memory, executive function, visuospatial function, and language, but not attention or orientation. There was no evidence for effect modification by cognitive reserve in any of these models (Supplemental eTables 2-5).

\section{Discussion}

We examined the modifying effects of markers of cognitive reserve on the associations between cerebrovascular brain injury and cognition. As expected, nonlacunar infarcts and higher WMH were associated with lower cognition. Five of the 6 markers of cognitive reserve-high education (most strongly), greater height, greater leisure physical activity, being in a marital partnership, and participation in social groups - were independently associated with better cognition (leisure physical activity was only significant for DSST). It is possible that leisure physical activity was only associated with DSST and not MoCA because DSST is a more sensitive and continuous measure, resulting in greater sensitivity to detect smaller effects on cognition. The composite cognitive reserve score, based on these 5 significant reserve variables, was also associated with better cognition. However, contrary to our prespecified hypothesis, we failed to find evidence that these cognitive reserve markers modified the effect of covert vascular brain injury (defined as either nonlacunar infarcts or high WMH) on cognition.

Of the few studies on cognitive reserve in persons with cerebral small vessel disease, research has mostly focused on education as a modifier of the relationship between $\mathrm{WMH}$ and cognition. ${ }^{20}$ A prior review identified 4 studies in the general population that found that the adverse effect of $\mathrm{WMH}$ on cognition was attenuated in persons with higher education. $^{21-24}$ A more recent publication from the Leukoaraiosis and Disability (LADIS) study showed that the 

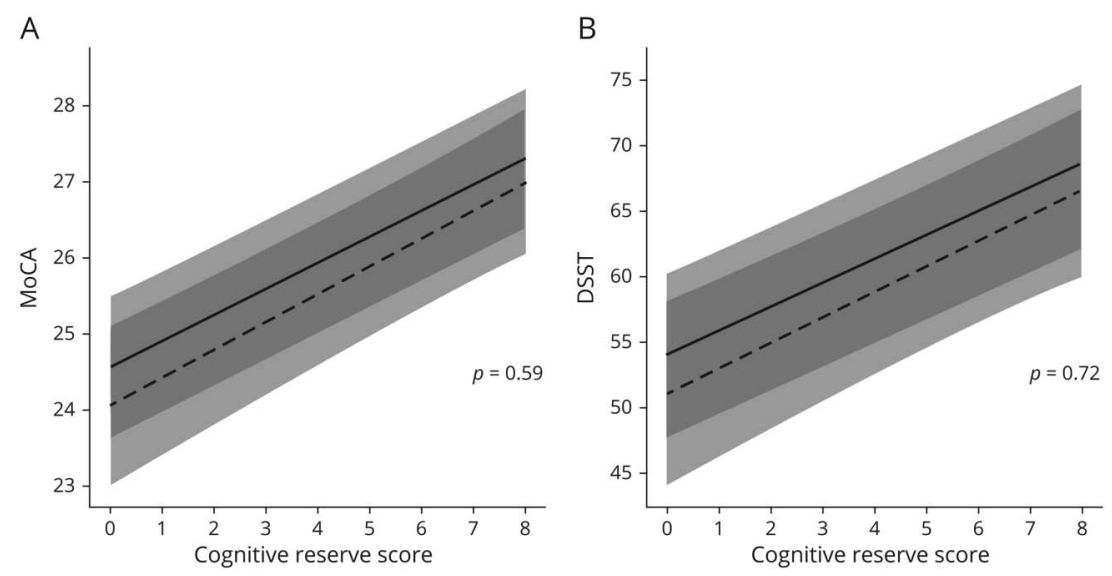

Association between composite cognitive reserve
score and cognition ([A] Montreal Cognitive Assess-
ment [MoCA] and [B] Digit Symbol Substitution Test
[DSST]) in the presence (dashed line) and absence
(solid line) of vascular brain injury, with $p$ values for
the interaction between cognitive reserve score and
vascular brain injury. Gray bands indicate $95 \%$ con-
fidence limits. Higher cognitive reserve score was
associated with higher cognitive function and vas-
cular brain injury was associated with lower cognitive
function (see Table 3 for details). However, there was
no interaction between cognitive reserve score and
vascular brain injury for either MoCA or DSST as
evidenced by the nearly parallel slopes and non-
significant tests of interaction.

3-year rate of cognitive decline in persons with high WMH was slower in persons with high education compared to low education. ${ }^{3}$ Two studies found that the association of CBI on cognition was attenuated in persons with higher education. ${ }^{25,26}$ There are few studies on markers other than education. In the LADIS study, the association of WMH with 3-year rate of cognitive decline was attenuated in persons with higher occupational attainment, defined as a white collar or professional occupation. ${ }^{3}$ Another study found that the association of high WMH with lower cognition was attenuated by high cognitive leisure activity such as playing board games, social activities, or doing puzzles. ${ }^{27}$ This shows the need for datasets that evaluate the effects of cognitive reserve variables other than education alone.

These previous studies suggested that higher cognitive reserve may attenuate the negative effects of cerebral small vessel disease on cognition, but we did not observe this in our study. The reason for the differences in study findings are not clear but could relate to different cohort characteristics. Compared to other studies, our cohort was younger (mean age 58 compared to $>65$ for the other studies), more contemporary (recruited in 2010-2019 instead of the 1990s to early 2000s), and more highly educated, with the majority having a college or university education. We also examined more cognitive reserve variables compared to other studies, providing a more holistic approach to cognitive reserve that intends to capture a variety of cognitive reserve markers.

Although we did not find strong evidence for effect modification, we did find that lifestyle and social factors were independently associated with higher cognition regardless of the presence of MRI-defined vascular brain injury. Education is well known to be associated with higher cognition and low education is a risk factor for dementia. Higher physical activity has been associated with lower risk for dementia ${ }^{28}$ although the extent to which exercise programs prevent dementia is unclear. ${ }^{29}$ Higher social participation and avoidance of social isolation and loneliness may protect against dementia, with $41 \%$ increased relative risk in persons with low social participation. ${ }^{30}$ Being in a marital partnership has been associated with better cognition and lower risk of dementia; in a recent systematic review, being single throughout life was associated with $40 \%$ increased risk. ${ }^{31}$ High psychological stress, including stress in midlife, has been associated with $60 \%$ increased risk for later-life dementia. ${ }^{32}$ Greater height does not directly influence cognition but could be a proxy for healthier early-life development, and has been associated with lower risk for dementia in some studies. ${ }^{13}$ Higher synaptic density and better functioning brain networks are hypothesized to underlie the potential beneficial effects of these factors on cognitive performance and risk for dementia. ${ }^{20}$

Study strengths include a large population-based sample. As for limitations, although our cross-sectional design allows us to make inferences regarding the modifying effects of cognitive reserve factors on the association between covert cerebrovascular disease and cognition, it does not allow us to determine the temporal association between cognitive reserve factors and change in cognition over the lifespan. Although it is plausible that the cognitive reserve variables cause better cognition, we cannot exclude that the direction of causation is reversed. That is, early cognitive decline might lead to less physical activity, less engagement in social groups, and greater likelihood of being single. This concern for reverse causation is somewhat mitigated as we looked at early subclinical cognitive changes in persons without dementia, where even low cognitive performers were within normal ranges. Longitudinal follow-up of this cohort is planned, in which we can evaluate the long-term risk of dementia according to level of education, social activities, marital status, height, and physical activity. There may be genetic contributors to cognitive reserve, but they have not been analyzed in our study. Future studies should investigate the role that physiologic factors, including cerebrovascular reactivity, play in the development of cognitive reserve. ${ }^{33}$ Another potential limitation is the use of brief 
cognitive assessment tools, which consisted of a frequently used cognitive screening tool (MoCA) and a test of processing speed (DSST). However, these tools are well validated, have been used in other population-based studies, and are sensitive to aging, to change over time, and to the presence of covert vascular brain injury. To provide a straightforward clinical interpretation, we dichotomized cut points for our cognitive reserve variables, which could have led to some loss of statistical power.

Our data suggest that enhancing cognitive reserve through better early life education, physical activity, and social engagement may potentially help improve cognition but is not likely to mitigate the deleterious effects of covert cerebrovascular disease. Therefore, an effective dementia prevention strategy will need to promote cognitive-enhancing social and behavioral activities while reducing the risk of incident CBI and $\mathrm{WMH}$ progression. This should include individual and health policy interventions to improve early life education and promote active social participation, strong family relationships, and increased physical activity, as well as new strategies to reduce progression of covert cerebrovascular disease. ${ }^{34}$

\section{Study Funding}

Dr. Smith had full access to all the data in the study and takes responsibility for the integrity of the data and the accuracy of the data analysis. The funders played no role in the design and conduct of the study; collection, management, analysis, or interpretation of the data; preparation, review, or approval of the manuscript; or the decision to submit the manuscript for publication. CAHHM was funded by the Canadian Partnership Against Cancer (CPAC), Heart and Stroke Foundation of Canada, and the Canadian Institutes of Health Research (CIHR). Financial contributions were also received from the Population Health Research Institute. Dr. Sonia Anand received CIHR Foundation grant FDN-143255; Dr. Jack Tu, CIHR Foundation grant FDN-143313; and Dr. Eric Smith, CIHR Foundation grant FDN-154317. In-kind contributions were received from Dr. Alan Moody and Dr. Sandra E. Black from Sunnybrook Hospital, Toronto, for MRI reading costs, and Bayer AG for provision of IV contrast. The Canadian Partnership for Tomorrow Project is funded by CPAC, Genome Quebec, Genome Canada, Ontario Institute for Cancer Research Government of Alberta, and Alberta Cancer Foundation. The Montreal Heart Institute Biobank is funded by André Desmarais and France Chrétien-Desmarais and the Montreal Heart Institute Foundation. The PURE study is an investigator-initiated study that was funded by the Population Health Research Institute, Hamilton Health Sciences Research Institute (HHSRI), the Canadian Institutes of Health Research, Heart and Stroke Foundation of Ontario, Support from Canadian Institutes of Health Research's Strategy for Patient Oriented Research, through the Ontario SPOR Support Unit, as well as the Ontario Ministry of Health and Long-Term Care and through unrestricted grants from several pharmaceutical companies (with major contributions from AstraZeneca [Canada], Sanofi-Aventis [France and Canada], Boehringer
Ingelheim [Germany and Canada], Servier, and GlaxoSmithKline), and additional contributions from Novartis and King Pharma and from various national or local organizations in participating countries. In Canada, there was additional support for PURE from an unrestricted grant from Dairy Farmers of Canada and the National Dairy Council (US), Public Health Agency of Canada, and Champlain Cardiovascular Disease Prevention Network. The PURE Poland substudy was partially funded by Polish Ministry of Science and Higher Education grant 290/W-PURE/2008/0 and the MRI substudy was supported by a Polish National Science Centre grant (NCN 2015/17/B/NZ7-02963).

\section{Disclosure}

The authors report no conflicts of interest and no relevant disclosures. Go to Neurology.org/ $\mathrm{N}$ for full disclosures.

\section{Publication History}

Received by Neurology February 2, 2021. Accepted in final form September 3, 2021.

\begin{tabular}{|c|c|c|}
\hline Name & Location & Contribution \\
\hline $\begin{array}{l}\text { Romella Durrani, } \\
\text { PhD }\end{array}$ & $\begin{array}{l}\text { Department of Clinical } \\
\text { Neurosciences and } \\
\text { Hotchkiss Brain Institute, } \\
\text { University of Calgary, } \\
\text { Canada }\end{array}$ & $\begin{array}{l}\text { Cleaned and analyzed the } \\
\text { data, interpreted the } \\
\text { results of study analyses, } \\
\text { and wrote the manuscript }\end{array}$ \\
\hline $\begin{array}{l}\text { Matthias G. } \\
\text { Friedrich, MD }\end{array}$ & $\begin{array}{l}\text { Department of Medicine } \\
\text { and Diagnostic Radiology, } \\
\text { McGill University, } \\
\text { Montreal, Canada }\end{array}$ & $\begin{array}{l}\text { Collected study data, } \\
\text { interpreted the results of } \\
\text { study analyses, and } \\
\text { revised the manuscript } \\
\text { critically for important } \\
\text { intellectual content }\end{array}$ \\
\hline $\begin{array}{l}\text { Karleen M. } \\
\text { Schulze, MMath }\end{array}$ & $\begin{array}{l}\text { Population Health } \\
\text { Research Institute, } \\
\text { Hamilton Health Sciences, } \\
\text { and Department of } \\
\text { Medicine, McMaster } \\
\text { University, Hamilton, } \\
\text { Canada }\end{array}$ & $\begin{array}{l}\text { Generated the statistical } \\
\text { models, analyzed the } \\
\text { data, interpreted the } \\
\text { results of study analyses, } \\
\text { and revised the } \\
\text { manuscript critically for } \\
\text { important intellectual } \\
\text { content }\end{array}$ \\
\hline $\begin{array}{l}\text { Philip Awadalla, } \\
\text { PhD }\end{array}$ & $\begin{array}{l}\text { Department of Molecular } \\
\text { Genetics, Ontario Institute } \\
\text { for Cancer Research, } \\
\text { University of Toronto, } \\
\text { Canada }\end{array}$ & $\begin{array}{l}\text { Collected study data, } \\
\text { interpreted the results } \\
\text { of study analyses, } \\
\text { and revised the } \\
\text { manuscript critically } \\
\text { for important } \\
\text { intellectual content }\end{array}$ \\
\hline $\begin{array}{l}\text { Kumar } \\
\text { Balasubramanian, } \\
\text { MSc }\end{array}$ & $\begin{array}{l}\text { Population Health } \\
\text { Research Institute, } \\
\text { Hamilton Health Sciences, } \\
\text { and Department of } \\
\text { Medicine, McMaster } \\
\text { University, Hamilton, } \\
\text { Canada }\end{array}$ & $\begin{array}{l}\text { Collected study data, } \\
\text { interpreted the results of } \\
\text { study analyses, and } \\
\text { revised the manuscript } \\
\text { critically for important } \\
\text { intellectual content }\end{array}$ \\
\hline Sandra Black, MD & $\begin{array}{l}\text { Department of Medicine } \\
\text { (Neurology), Sunnybrook } \\
\text { Health Sciences Centre, } \\
\text { and Sunnybrook Research } \\
\text { Institute, Sunnybrook } \\
\text { Health Sciences Centre, } \\
\text { University of Toronto, } \\
\text { Canada }\end{array}$ & $\begin{array}{l}\text { Co-supervised brain MRI } \\
\text { analyses, interpreted the } \\
\text { results of study analyses, } \\
\text { and revised the } \\
\text { manuscript critically for } \\
\text { important intellectual } \\
\text { content }\end{array}$ \\
\hline
\end{tabular}


Appendix (continued)

\begin{tabular}{lll}
\hline Name & Location & Contribution \\
\hline $\begin{array}{l}\text { Philippe Broet, } \\
\text { MD, PhD }\end{array}$ & $\begin{array}{l}\text { Department of Preventive } \\
\text { and Social Medicine, École } \\
\text { de Santé Publique, }\end{array}$ & $\begin{array}{l}\text { Collected study data, } \\
\text { interpreted the results of } \\
\text { Study analyses, and }\end{array}$ \\
& $\begin{array}{l}\text { Université de Montreal, } \\
\text { and Research Centre, CHU } \\
\text { Sainte Justine, Montreal, } \\
\text { Canada }\end{array}$ & $\begin{array}{l}\text { revitically for intellectual content } \\
\text { inteript }\end{array}$ \\
&
\end{tabular}

\begin{tabular}{|c|c|c|}
\hline $\begin{array}{l}\text { David Busseuil, } \\
\text { PhD }\end{array}$ & $\begin{array}{l}\text { Research Centre, Montreal } \\
\text { Heart Institute, Université } \\
\text { de Montréal Quebec, } \\
\text { Canada }\end{array}$ & $\begin{array}{l}\text { Collected study data, } \\
\text { interpreted the results of } \\
\text { study analyses, and } \\
\text { revised the manuscript } \\
\text { critically for important } \\
\text { intellectual content }\end{array}$ \\
\hline Dipika Desai, MSc & $\begin{array}{l}\text { Population Health } \\
\text { Research Institute, } \\
\text { Hamilton Health Sciences, } \\
\text { McMaster University, } \\
\text { Hamilton, Canada }\end{array}$ & $\begin{array}{l}\text { Collected study data, } \\
\text { interpreted the results of } \\
\text { study analyses, and } \\
\text { revised the manuscript } \\
\text { critically for important } \\
\text { intellectual content }\end{array}$ \\
\hline $\begin{array}{l}\text { Trevor Dummer, } \\
\text { PhD }\end{array}$ & $\begin{array}{l}\text { School of Population and } \\
\text { Public Health, University of } \\
\text { British Columbia } \\
\text { Vancouver, Canada }\end{array}$ & $\begin{array}{l}\text { Collected study data, } \\
\text { interpreted the results of } \\
\text { study analyses, and } \\
\text { revised the manuscript } \\
\text { critically for important } \\
\text { intellectual content }\end{array}$ \\
\hline $\begin{array}{l}\text { Alexander Dick, } \\
\text { MD, FRCPC }\end{array}$ & $\begin{array}{l}\text { Division of Cardiology, } \\
\text { University of Ottawa Heart } \\
\text { Institute, University of } \\
\text { Ottawa, Canada }\end{array}$ & $\begin{array}{l}\text { Collected study data, } \\
\text { interpreted the results of } \\
\text { study analyses, and } \\
\text { revised the manuscript } \\
\text { critically for important } \\
\text { intellectual content }\end{array}$ \\
\hline
\end{tabular}

\begin{tabular}{lll}
\hline Jason Hicks, MSc & Atlantic PATH, Dalhousie & Collected study data, \\
& University, Halifax, Canada & interpreted the results of \\
& study analyses, and \\
& revised the manuscript \\
& critically for important \\
& intellectual content
\end{tabular}

\begin{tabular}{|c|c|c|}
\hline Thomas lype, MD & $\begin{array}{l}\text { Department of Neurology, } \\
\text { Government Medical } \\
\text { College } \\
\text { Thiruvananthapuram, } \\
\text { India }\end{array}$ & $\begin{array}{l}\text { Collected study data, } \\
\text { interpreted the results of } \\
\text { study analyses, and } \\
\text { revised the manuscript } \\
\text { critically for important } \\
\text { intellectual content }\end{array}$ \\
\hline David Kelton, MD & $\begin{array}{l}\text { Diagnostic Imaging, } \\
\text { Brampton Civic Hospital, } \\
\text { William Osler Health } \\
\text { System, Etobicoke, Canada }\end{array}$ & $\begin{array}{l}\text { Collected study data, } \\
\text { interpreted the results of } \\
\text { study analyses, and } \\
\text { revised the manuscript } \\
\text { critically for important } \\
\text { intellectual content }\end{array}$ \\
\hline $\begin{array}{l}\text { Anish Kirpalani, } \\
\text { MD }\end{array}$ & $\begin{array}{l}\text { Department of Medical } \\
\text { Imaging, St. Michael's } \\
\text { Hospital, University of } \\
\text { Toronto, Canada }\end{array}$ & $\begin{array}{l}\text { Collected study data, } \\
\text { interpreted the results of } \\
\text { study analyses, and } \\
\text { revised the manuscript } \\
\text { critically for important } \\
\text { intellectual content }\end{array}$ \\
\hline Scott A. Lear, PhD & $\begin{array}{l}\text { Faculty of Health Sciences, } \\
\text { Simon Fraser University, } \\
\text { Burnaby, Canada }\end{array}$ & $\begin{array}{l}\text { Collected study data, } \\
\text { interpreted the results of } \\
\text { study analyses, and } \\
\text { revised the manuscript } \\
\text { critically for important } \\
\text { intellectual content }\end{array}$ \\
\hline $\begin{array}{l}\text { Jonathon Leipsic, } \\
\text { MD }\end{array}$ & $\begin{array}{l}\text { Department of Radiology, } \\
\text { University of British } \\
\text { Columbia, St. Paul's } \\
\text { Hospital, Vancouver, } \\
\text { Canada }\end{array}$ & $\begin{array}{l}\text { Collected study data, } \\
\text { interpreted the results of } \\
\text { study analyses, and } \\
\text { revised the manuscript } \\
\text { critically for important } \\
\text { intellectual content }\end{array}$ \\
\hline
\end{tabular}

Appendix (continued)

\begin{tabular}{lll}
\hline Name & Location & Contribution \\
\hline Wei Li, PhD & $\begin{array}{l}\text { National Center for } \\
\text { Cardiovascular Diseases, } \\
\text { Chinese Academy of } \\
\text { Medical Sciences, Fu Wai } \\
\text { Hospital, Beijing, China }\end{array}$ & $\begin{array}{l}\text { Collected study data, } \\
\text { interpreted the results of } \\
\text { study analyses, } \\
\text { and revised the } \\
\text { manuscript critically for } \\
\text { important intellectual } \\
\text { content }\end{array}$ \\
& & $\begin{array}{l}\text { Collected study data, } \\
\text { interpreted the results } \\
\text { of study analyses, } \\
\text { McCreary, PhD }\end{array}$ \\
\hline Department of Radiology \\
and Clinical & $\begin{array}{l}\text { Neurosciences, University } \\
\text { of Calgary, Canada }\end{array}$ & $\begin{array}{l}\text { manuscript critically } \\
\text { for important } \\
\text { intellectual content }\end{array}$ \\
& &
\end{tabular}

\begin{tabular}{ll}
\hline Alan R. Moody, MD & Department of Medical \\
& Imaging, Sunnybrook \\
& Health Sciences Centre, \\
& University of Toronto, \\
& Canada
\end{tabular}

Collected study data, interpreted the results of study analyses, and revised the manuscript critically for important intellectual content

\begin{tabular}{|c|c|}
\hline $\begin{array}{l}\text { Michael D. } \\
\text { Noseworthy, PhD }\end{array}$ & $\begin{array}{l}\text { Department of Electrical } \\
\text { and Computer } \\
\text { Engineering, School of } \\
\text { Biomedical Engineering, } \\
\text { McMaster University; and } \\
\text { Diagnostic Imaging, St. } \\
\text { Joseph's Health Care, } \\
\text { Hamilton, Canada }\end{array}$ \\
\hline
\end{tabular}

Collected study data, interpreted the results of study analyses, and revised the manuscript critically for important intellectual content

\begin{tabular}{ll}
\hline Grace Parraga, & Department of Medical \\
PhD & Biophysics and Robarts \\
& Research Institute, \\
& Western University, \\
& London, UK
\end{tabular}

Collected study data, interpreted the results of study analyses, and revised the manuscript critically for important intellectual content

Paul Poirier, MD, Institut de Cardiologie et Collected study data, PhD de Pneumologie de interpreted the results Quebec, Université Laval, of study analyses, Canada and revised the manuscript critically for important intellectual content

\begin{tabular}{|c|c|c|}
\hline $\begin{array}{l}\text { Sumathy } \\
\text { Rangarajan, MSc }\end{array}$ & $\begin{array}{l}\text { Population Health } \\
\text { Research Institute, } \\
\text { Hamilton Health Sciences, } \\
\text { and Department of } \\
\text { Medicine, McMaster } \\
\text { University, Hamilton, } \\
\text { Canada }\end{array}$ & $\begin{array}{l}\text { Collected study data, } \\
\text { interpreted the results } \\
\text { of study analyses, and } \\
\text { revised the manuscript } \\
\text { critically for important } \\
\text { intellectual content }\end{array}$ \\
\hline $\begin{array}{l}\text { Dorota Szczesniak, } \\
\text { PhD }\end{array}$ & $\begin{array}{l}\text { Department of Psychiatry, } \\
\text { Wroclaw Medical } \\
\text { University, Poland }\end{array}$ & $\begin{array}{l}\text { Collected study data, } \\
\text { interpreted the results } \\
\text { of study analyses, } \\
\text { and revised the } \\
\text { manuscript critically } \\
\text { for important } \\
\text { intellectual content }\end{array}$ \\
\hline Andrzej Szuba, MD & $\begin{array}{l}\text { Department of Angiology, } \\
\text { Wroclaw Medical } \\
\text { University, Poland }\end{array}$ & $\begin{array}{l}\text { Collected study data, } \\
\text { interpreted the results } \\
\text { of study analyses, } \\
\text { and revised the } \\
\text { manuscript critically } \\
\text { for important } \\
\text { intellectual content }\end{array}$ \\
\hline $\begin{array}{l}\text { Jean-Claude Tardif, } \\
\text { MD }\end{array}$ & $\begin{array}{l}\text { Research Centre, Montreal } \\
\text { Heart Institute, Université } \\
\text { de Montréal, Quebec, } \\
\text { Canada }\end{array}$ & $\begin{array}{l}\text { Supervised the combined } \\
\text { core lab for imaging } \\
\text { analysis, and revised } \\
\text { the manuscript critically } \\
\text { for important } \\
\text { intellectual content }\end{array}$ \\
\hline
\end{tabular}


Appendix (continued)

\begin{tabular}{|c|c|c|}
\hline Name & Location & Contribution \\
\hline $\begin{array}{l}\text { Koon Teo, MBBCH, } \\
\text { PhD }\end{array}$ & $\begin{array}{l}\text { Population Health } \\
\text { Research Institute, } \\
\text { Hamilton Health Sciences, } \\
\text { Department of Medicine, } \\
\text { and Department of Health } \\
\text { Evidence and Impact, } \\
\text { McMaster University, } \\
\text { Hamilton, Canada }\end{array}$ & $\begin{array}{l}\text { Collected study data, } \\
\text { interpreted the results of } \\
\text { study analyses, and } \\
\text { revised the manuscript } \\
\text { critically for important } \\
\text { intellectual content }\end{array}$ \\
\hline $\begin{array}{l}\text { Jennifer E. Vena, } \\
\text { PhD }\end{array}$ & $\begin{array}{l}\text { Cancer Research and } \\
\text { Analytics, Cancer Care } \\
\text { Control Alberta, Alberta } \\
\text { Health Services Calgary, } \\
\text { Canada }\end{array}$ & $\begin{array}{l}\text { Collected study data, } \\
\text { interpreted the results of } \\
\text { study analyses, and } \\
\text { revised the manuscript } \\
\text { critically for important } \\
\text { intellectual content }\end{array}$ \\
\hline $\begin{array}{l}\text { Katarzyna } \\
\text { Zatonska, MD }\end{array}$ & $\begin{array}{l}\text { Department of Social } \\
\text { Medicine, Wroclaw } \\
\text { Medical University, Poland }\end{array}$ & $\begin{array}{l}\text { Collected study data, } \\
\text { interpreted the results of } \\
\text { study analyses, and } \\
\text { revised the manuscript } \\
\text { critically for important } \\
\text { intellectual content }\end{array}$ \\
\hline
\end{tabular}

\section{Anna Zimny, MD Department of General Collected study data,} and Interventional interpreted the results of Radiology and study analyses, and Neuroradiology, Wroclaw revised the manuscript Medical University, Poland critically for important intellectual content

\begin{tabular}{ll}
\hline Douglas S. Lee, MD, & Department of Medicine, \\
PhD & University of Toronto, \\
& ICES, Canada
\end{tabular}

Collected study data, interpreted the results of study analyses, and revised the manuscript critically for important intellectual content

\begin{tabular}{|c|c|c|}
\hline $\begin{array}{l}\text { Salim Yusuf, MBBS, } \\
\text { DPhil }\end{array}$ & $\begin{array}{l}\text { Population Health } \\
\text { Research Institute, } \\
\text { Hamilton Health Sciences, } \\
\text { Department of Medicine, } \\
\text { and Department of Health } \\
\text { Evidence and Impact, } \\
\text { McMaster University, } \\
\text { Hamilton, Canada }\end{array}$ & $\begin{array}{l}\text { Obtained study funding, } \\
\text { interpreted the results of } \\
\text { study analyses, and } \\
\text { revised the manuscript } \\
\text { critically for important } \\
\text { intellectual content }\end{array}$ \\
\hline $\begin{array}{l}\text { Sonia S. Anand, } \\
\text { MD, PhD }\end{array}$ & $\begin{array}{l}\text { Population Health } \\
\text { Research Institute, } \\
\text { Hamilton Health Sciences, } \\
\text { Department of Medicine, } \\
\text { and } \\
\text { Department of Health } \\
\text { Evidence and Impact, } \\
\text { McMaster University, } \\
\text { Hamilton, Canada }\end{array}$ & $\begin{array}{l}\text { Obtained study funding, } \\
\text { interpreted the results of } \\
\text { study analyses, and } \\
\text { revised the manuscript } \\
\text { critically for important } \\
\text { intellectual content }\end{array}$ \\
\hline $\begin{array}{l}\text { Eric E. Smith, MD, } \\
\text { MPH }\end{array}$ & $\begin{array}{l}\text { Department of Clinical } \\
\text { Neurosciences and } \\
\text { Hotchkiss Brain Institute, } \\
\text { University of Calgary, } \\
\text { Canada }\end{array}$ & $\begin{array}{l}\text { Had full access to all the } \\
\text { data in the study and takes } \\
\text { responsibility for the } \\
\text { integrity of the data, the } \\
\text { accuracy of the data } \\
\text { analysis, and the conduct } \\
\text { of the research }\end{array}$ \\
\hline
\end{tabular}

\section{References}

1. Stern Y. Cognitive reserve in ageing and Alzheimer's disease. Lancet Neurol. 2012; 11(11):1006-1012.

2. Durrani R, Hill MD, Smith EE. Preventing covert brain infarct-related cognitive impairment and dementia. Can J Neurol Sci. 2020:1-25.

3. Jokinen H, Melkas S, Madureira $S$, et al. Cognitive reserve moderates long-term cognitive and functional outcome in cerebral small vessel disease. J Neurol Neurosurg Psychiatry. 2016;87(12):1296-1302.
4. Anand SS, Tu JV, Awadalla P, et al. Rationale, design, and methods for Canadian Alliance for Healthy Hearts and Minds cohort study (CAHHM): a pan-Canadian cohort study. BMC Public Health. 2016;16:650.

5. Smith EE, O’Donnell M, Dagenais G, et al. Early cerebral small vessel disease and brain volume, cognition, and gait. Ann Neurol. 2015;77(2):251-261.

6. Dummer TJB, Awadalla P, Boileau C, et al. The Canadian Partnership for Tomorrow Project: a pan-Canadian platform for research on chronic disease prevention. CMAJ. 2018;190(23):E710-E717.

7. Yusuf S, Islam S, Chow CK, et al. Use of secondary prevention drugs for cardiovascular disease in the community in high-income, middle-income, and low-income countries (the PURE study): a prospective epidemiological survey. Lancet. 2011;378(9798):1231-1243.

8. Scarmeas N, Levy G, Tang MX, Manly J, Stern Y. Influence of leisure activity on the incidence of Alzheimer's disease. Neurology. 2001;57(12):2236-2242.

9. Stern Y, Gurland B, Tatemichi TK, Tang MX, Wilder D, Mayeux R. Influence of education and occupation on the incidence of Alzheimer's disease. JAMA. 1994; 271(13):1004-1010.

10. Petot GJ, Vega U, Traore F, et al. Height and Alzheimer's disease: findings from a casecontrol study. J Alzheimers Dis. 2007;11(3):337-341.

11. Hakansson K, Rovio S, Helkala EL, et al. Association between mid-life marital status and cognitive function in later life: population based cohort study. BMJ. 2009;339:b2462.

12. Rosengren A, Hawken S, Ounpuu S, et al. Association of psychosocial risk factors with risk of acute myocardial infarction in 11119 cases and 13648 controls from 52 countries (the INTERHEART study): case-control study. Lancet. 2004;364:953-962.

13. Russ TC, Kivimaki M, Starr JM, Stamatakis E, Batty GD. Height in relation to dementia death: individual participant meta-analysis of $18 \mathrm{UK}$ prospective cohort studies. Br J Psychiatry. 2014;205(5):348-354.

14. Lear SA, Hu W, Rangarajan S, et al. The effect of physical activity on mortality and cardiovascular disease in 130000 people from 17 high-income, middle-income, and low-income countries: the PURE study. Lancet. 2017;390(10113):2643-2654.

15. Nasreddine ZS, Phillips NA, Bedirian V, et al. The Montreal Cognitive Assessment, MoCA: a brief screening tool for mild cognitive impairment. J Am Geriatr Soc. 2005; 53(4):695-699.

16. Merz ZC, Lace JW, Eisenstein AM, Grant AF. Examination of Wechsler Adult In telligence Scale-Fourth Edition short-form IQ estimations in an outpatient psychoeducational sample. Appl Neuropsychol Adult. 2019:1-10.

17. Freitas S, Simoes MR, Maroco J, Alves L, Santana I. Construct validity of the Montreal Cognitive Assessment (MoCA). J Int Neuropsychol Soc. 2012;18(2):242-250.

18. Duchesne $\mathrm{S}$, Chouinard I, Potvin $\mathrm{O}$, et al. The Canadian dementia imaging protocol: harmonizing national cohorts. J Magn Reson Imaging. 2019;49(2):456-465.

19. Wardlaw JM, Smith EE, Biessels GJ, et al. Neuroimaging standards for research into small vessel disease and its contribution to ageing and neurodegeneration. Lancet Neurol. 2013;12(8):822-838.

20. Pinter D, Enzinger C, Fazekas F. Cerebral small vessel disease, cognitive reserve and cognitive dysfunction. J Neurol. 2015;262(11):2411-2419.

21. Dufouil C, Alperovitch A, Tzourio C. Influence of education on the relationship between white matter lesions and cognition. Neurology. 2003;60(5):831-836.

22. Nebes RD, Meltzer CC, Whyte EM, et al. The relation of white matter hyperintensities to cognitive performance in the normal old: education matters. Neuropsychol. 2006;13(3-4):326-340.

23. Brickman AM, Siedlecki KL, Muraskin J, et al. White matter hyperintensities and cognition: testing the reserve hypothesis. Neurobiol Aging. 2011;32(9):1588-1598

24. Vemuri P, Lesnick TG, Przybelski SA, et al. Vascular and amyloid pathologies are in dependent predictors of cognitive decline in normal elderly. Brain. 2015;138pt 3):761-771.

25. Elkins JS, Longstreth WT Jr., Manolio TA, Newman AB, Bhadelia RA, Johnston SC Education and the cognitive decline associated with MRI-defined brain infarct. Neurology. 2006;67(3):435-440.

26. Farfel JM, Nitrini R, Suemoto CK, et al. Very low levels of education and cognitive reserve: a clinicopathologic study. Neurology. 2013;81(7):650-657.

27. Saczynski JS, Jonsdottir MK, Sigurdsson S, et al. White matter lesions and cognitive performance: the role of cognitively complex leisure activity. J Gerontol A Biol Sci Med Sci. 2008;63(8):848-854.

28. Blondell SJ, Hammersley-Mather R, Veerman JL. Does physical activity prevent cognitive decline and dementia? A systematic review and meta-analysis of longitudinal studies. BMC Public Health. 2014;14:510.

29. Sink KM, Espeland MA, Castro CM, et al. Effect of a 24-Month physical activity intervention vs health education on cognitive outcomes in sedentary older adults: the LIFE randomized trial. JAMA. 2015;314(8):781-790.

30. Kuiper JS, Zuidersma M, Oude Voshaar RC, et al. Social relationships and risk of dementia: a systematic review and meta-analysis of longitudinal cohort studies. Ageing Res Rev. 2015;22:39-57

31. Sommerlad A, Ruegger J, Singh-Manoux A, Lewis G, Livingston G. Marriage and risk of dementia: systematic review and meta-analysis of observational studies. J Neurol Neurosurg Psychiatry. 2018;89(3):231-238

32. Johansson L, Guo X, Waern M, et al. Midlife psychological stress and risk of dementia: a 35-year longitudinal population study. Brain. 2010;133(pt 8):2217-2224.

33. Siniscalchi A, Gray C, Malferrari G. Ultrasound diagnostic method in vascular dementia: current concepts. Curr Med Imaging. 2021;17(4):507-512.

34. Smith EE, Markus HS. New treatment approaches to modify the course of cerebral small vessel diseases. Stroke. 2020;51(1):38-46. 


\section{Neurology}

\section{Effect of Cognitive Reserve on the Association of Vascular Brain Injury With Cognition: Analysis of the PURE and CAHHM Studies}

Romella Durrani, Matthias G. Friedrich, Karleen M. Schulze, et al.

Neurology 2021;97;e1707-e1716 Published Online before print September 9, 2021

DOI 10.1212/WNL.0000000000012765

This information is current as of September 9, 2021

\section{Updated Information \&} Services

References

Subspecialty Collections

Permissions \& Licensing

Reprints including high resolution figures, can be found at: http://n.neurology.org/content/97/17/e1707.full

This article cites 32 articles, 9 of which you can access for free at: http://n.neurology.org/content/97/17/e1707.full\#ref-list-1

This article, along with others on similar topics, appears in the following collection(s):

All Cerebrovascular disease/Stroke

http://n.neurology.org/cgi/collection/all_cerebrovascular_disease_strok e

All Clinical Neurology

http://n.neurology.org/cgi/collection/all_clinical_neurology

All Cognitive Disorders/Dementia

http://n.neurology.org/cgi/collection/all_cognitive_disorders_dementia Cognitive aging

http://n.neurology.org/cgi/collection/cognitive_aging

Vascular dementia

http://n.neurology.org/cgi/collection/vascular_dementia

Information about reproducing this article in parts (figures,tables) or in its entirety can be found online at:

http://www.neurology.org/about/about_the_journal\#permissions

Information about ordering reprints can be found online:

http://n.neurology.org/subscribers/advertise

Neurology ${ }^{\circledR}$ is the official journal of the American Academy of Neurology. Published continuously since 1951, it is now a weekly with 48 issues per year. Copyright Copyright (C) 2021 The Author(s). Published by Wolters Kluwer Health, Inc. on behalf of the American Academy of Neurology.. All rights reserved. Print ISSN: 0028-3878. Online ISSN: 1526-632X.

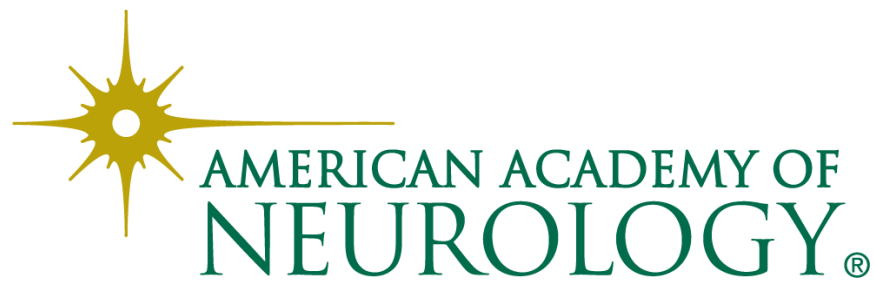

